\title{
The Effect of Micro-oxygenation on the Phenolic Composition, Quality and Aerobic Wine-Spoilage Microorganisms of Different South African Red Wines
}

\author{
W.J. du Toit ${ }^{1 *}$, K. Lisjak $^{2}$, J. Marais ${ }^{3}$ and M. du Toit ${ }^{1}$ \\ (1) Department of Viticulture and Oenology, Private Bag X1, 7620 Matieland (Stellenbosch), South Africa \\ (2) Agricultural Institute of Slovenia, Hacquetova 17, 1001 Ljubljana, Slovenia \\ (3) ARC Infruitec-Nietvoorbij, Private Bag X5026, 7599 Stellenbosch, South Africa
}

Submitted for publication: April 2006

Accepted for publication: May 2006

Key words: Micro-oxygenation, phenolic development, wine colour, wine microorganisms

\begin{abstract}
The effect of micro-oxygenation treatments on the composition of different South African red wines was evaluated. In some wines, micro-oxygenation led to an increase in colour density, with a corresponding change in colour, due to the formation of polymeric pigments. This increase also led to the red colour becoming more resistant to the bleaching effect of $\mathrm{SO}_{2}$. Micro-oxygenation also seemed to be more effective in increasing the colour densities of younger red wines than the older ones, although total red pigments were found to be highest in an older red wine that had received micro-oxygenation. Differences in the gelatine index were also observed over time. The micro-oxygenated and barrel-matured wines also had lower concentrations of catechin and the procyanidin B1, and showed a corresponding increase in polymeric pigment and polymeric phenols. Micro-oxygenation led to higher acetic acid bacteria counts, although no increase in volatile acidity was observed in these wines. A tasting panel preferred younger red wines that had undergone micro-oxygenation. In an older red wine prolonged micro-oxygenation led to the wine becoming over-aged, with an increase in the barnyard/medicinal character, which corresponded with an increase in Brettanomyces counts. Micro-oxygenation can be used to increase the quality of young red wines, but further research is needed in this area.
\end{abstract}

Micro-oxygenation is a process during which measured amounts of oxygen $\left(\mathrm{O}_{2}\right)$ are introduced to wines with the aim of bringing about desirable changes. Some of these include enhanced colour stability and intensity, softening of astringent tannins, and decreased reductive and vegetative aromas (Parish et al., 2000). Certain lactic acid bacteria, acetic acid bacteria and the yeast Brettanomyces are considered spoilage microorganisms of wine. Of these, acetic acid bacteria and Brettanomyces are aerobic microorganisms, and the introduction of $\mathrm{O}_{2}$ into wine can lead to their growth and subsequent spoilage of the wine (Du Toit et al., 2005). Micro-oxygenation has also been suggested as a means of replacing expensive oak barrels, by combining the process with alternative oak products in a stainless steel tank. During microoxygenation $\mathrm{O}_{2}$ is supplied in the form of compressed gas via a micron-size diffuser positioned close to the bottom of the tank. The technique of micro-oxygenation has been developed largely due to the work of Patrick Ducournau and Thierry Lemaire (Parish et al., 2000). During micro-oxygenation, $\mathrm{O}_{2}$ should be supplied at a slower rate than its rate of consumption by the wine to prevent unwanted accumulation in the headspace of the tank (Nikfardjam \& Dykes, 2003).

Although this technique has been in use for several years, limited scientific publications on micro-oxygenation are available. This is probably due to the large-scale experimental set-up required for the scientific investigation of its effect on wine, because most of the systems need a path length of $2.2 \mathrm{~m}$ for the $\mathrm{O}_{2}$ bubbles to dissolve in the wine (Parish et al., 2000). The effect of micro-oxygenation on the colour development of South African red wines and the effect that it has on younger red wines compared to older red wines is unclear. How a micro-oxygenation-treated wine compares to the same wine matured in an oak barrel is also not clear. The effect of micro-oxygenation on the microbial population of red wine is also not understood.

This study was undertaken to investigate the effect of microoxygenation after malolactic fermentation on the quality and composition of various commercial South African red wines.

\section{MATERIALS AND METHODS}

\section{Micro-oxygenation}

Different commercial cellars, with different red wines, participated in this project. The wines are listed in Table 1, together with the dosage of $\mathrm{O}_{2}$ added to each tank. In all cases a control tank of similar size, that received no micro-oxygenation, was kept. For wines $\mathrm{A}, \mathrm{B}$ and $\mathrm{D}$, the specific winemaker determined the dosage and duration of the treatment. All the wines were made according to standard red wine production methods, to the preference of the respective winemakers. In wines $\mathrm{A}$ and $\mathrm{B}$ the micro-oxygenation commenced just after completion of malolactic fermentation. In wines $\mathrm{C}$ and $\mathrm{D}$, the treatment commenced seven months after the

\footnotetext{
* Corresponding author: E-mail address: wdutoit@sun.ac.za
}

Acknowledgements: The authors would like to thank Reines Trading (agents for Parsec in South Africa) for the use of the micro-oxygenation equipment; Winetech for financial support; D.P. Groenewald and L. Kotzé for technical support; and members of the South African Pinotage Association who participated in the tastings. 
TABLE 1

Different commercial wines used in this study, with their origins and treatments.

\begin{tabular}{|c|c|c|c|}
\hline No & Cultivar and year & Origin of wine & Treatment \\
\hline A & Cabernet Sauvignon 2002 & Paarl & $\begin{array}{l}0,1.5 \text { and } 3 \mathrm{mg} \mathrm{O}_{2} / \mathrm{L} / \mathrm{month} \text { with oak staves, starting just after the completion of } \\
\text { malolactic fermentation. }\end{array}$ \\
\hline B & Red blend 2003 & Stellenbosch & $\begin{array}{l}0 \text { and } 4 \mathrm{mg} \mathrm{O}_{2} / \mathrm{L} / \mathrm{month} \text { with oak staves, starting just after the completion of } \\
\text { malolactic fermentation. }\end{array}$ \\
\hline $\mathrm{C}$ & Pinotage 2004 & $\begin{array}{l}\text { Paarl } \\
\text { (Stellenbosch University's cellar) }\end{array}$ & $\begin{array}{l}0,1.5 \text { and } 3 \mathrm{mg} \mathrm{O} / \mathrm{L} / \mathrm{month} \text { with oak staves, starting seven months after the completion } \\
\text { of malolactic fermentation. The same wine was also matured in an oak barrel of the same } \\
\text { wood as the staves used (USA MT+). }\end{array}$ \\
\hline $\mathrm{D}$ & Shiraz 2003 & Worcester & $\begin{array}{l}0 \text { and } 3 \mathrm{mg} \mathrm{O} / \mathrm{L} / \text { month with oak staves, starting seven months after the completion of } \\
\text { malolactic fermentation. }\end{array}$ \\
\hline
\end{tabular}

completion of malolactic fermentation. In wines A, B and D, the same oak staves (all French oak), at the same dosage, were used in both the control and the micro-oxygenation tanks. In wine $\mathrm{C}$, American oak staves (medium toast plus, MT+) were added to $70 \%$ of the internal surface of a 300-L oak barrel, following the supplier's recommendations, to simulate an oak barrel. The same Pinotage wine was also matured in a 300-L American oak barrel (medium toast plus). All wines were treated with micro-oxygenation equipment supplied by Parsec from Italy (distributed in South Africa by Reines Trading). This equipment doses the required $\mathrm{O}_{2}$ dosage in $\mathrm{mg} / \mathrm{L} / \mathrm{month}$. During the different treatments, the free $\mathrm{SO}_{2}$ levels were kept between 25 and $35 \mathrm{mg} / \mathrm{L}$, and the treatments were all conducted at cellar temperatures $\left(15-20^{\circ} \mathrm{C}\right)$.

\section{Phenolic analysis}

Various spectrophotometric analyses were conducted, according to Iland et al. (2000). These included wine colour density (the sum of the absorbance units at 420, 520 and $620 \mathrm{~nm}$ ), modified wine colour density, wine colour hue (at $420 \mathrm{~nm} / 520 \mathrm{~nm}$ ), modified wine colour hue, total red pigments (the absorbance units of all pigments measured at a low $\mathrm{pH}$ ), total phenolics (the absorbance units as measured at $280 \mathrm{~nm}$ ), degree of red pigment colouration (percentage of pigments in the red form), estimate of $\mathrm{SO}_{2}$ resistant pigments (the absorbance units of pigments which are not bleached by $\mathrm{SO}_{2}$, at $520 \mathrm{~nm}$ ) and modified degree of red pigment colouration (the modified version of the analysis negates the effect of $\mathrm{pH}$ and $\mathrm{SO}_{2}$ on the analysis). The fractions of co-pigmented anthocyanin, free anthocyanins and polymeric colour pigment content in the red wines were also determined according to the method of Boulton (2001). The estimates of $\mathrm{SO}_{2}$ resistant pigments and modified colour density were used to analyse these fractions. Total anthocyanin concentrations, total tannin concentrations, $\mathrm{HCl}$ index value (index of polymerisation of procyanidins) and gelatine index values (index of reactivity of phenolic molecules in wine towards gelatine) were conducted according to the methods described by Ribéreau-Gayon et al. (2000).

Reverse-phase high-performance liquid chromatography (HPLC) was performed on an Angilent 1100 series HPLC system equipped with a diode array detector (Angilent Technologies, Palo Alto, CA, USA). Data processing was done with Chemstation software (Hewlett-Packard, Waldbronn, Germany). A $100 \mathrm{~mm}$ x $4.6 \mathrm{~mm}$ Chromolith Peformance RP-18e column and pre-column (Merck) was used. The mobile phases used were: Solvent A, containing de-ionised water adjusted to $\mathrm{pH} 2.04$ with orthophosphoric acid (Reidel-de Haën), and Solvent B, consisting
TABLE 2

Gradient profile used in HPLC analysis.

\begin{tabular}{ccc}
\hline Time (min) & \% Solvent A & \% Solvent B \\
\hline 0 & 99 & 1 \\
2 & 99 & 1 \\
17 & 96 & 4 \\
31 & 90 & 10 \\
55 & 84 & 16 \\
75 & 75 & 25 \\
80 & 20 & 80 \\
84 & 20 & 80 \\
85 & 99 & 1 \\
\hline
\end{tabular}

of acetonitrile (Chromasolve, Reidel-de Haën) with 20\% of Solvent A. A flow rate of $2 \mathrm{ml} / \mathrm{min}$ was used and the column temperature was maintained at $35^{\circ} \mathrm{C}$. The gradient profile that was used is shown in Table 2.

Quantification was done using external standards: (+)-catechin hydrate (Fluka), gallic acid (Fluka), vanillic acid (Fluka), $p$ coumaric acid (Sigma), malvidin-3-glucoside (Fluka), ellagic acid (Fluka), quercetin-3-glucoside (Fluka) and quercitin (Extrasynthèse).

Flavan-3-ols were quantified at $280 \mathrm{~nm}$ as $\mathrm{mg} / \mathrm{L}$ catechin units, benzoic acids at $280 \mathrm{~nm}$ as $\mathrm{mg} / \mathrm{L}$ vanillic acid units, cinnamic acids at $320 \mathrm{~nm}$ as $\mathrm{mg} / \mathrm{L}$-coumaric acid units, anthocyanins at $520 \mathrm{~nm}$ as $\mathrm{mg} / \mathrm{L}$ malvidin-3-glucoside, flavonol-glucoside units at $360 \mathrm{~nm}$ as $\mathrm{mg} / \mathrm{L}$ quercetin-3-glucosides, and flavonol aglycones at $360 \mathrm{~nm}$ as $\mathrm{mg} / \mathrm{L}$ quercetin units.

\section{Sensory evaluation}

Two tastings of wine A were held during the course of the experiment. One was held 8 weeks after the treatment started and the other after 12 weeks. The panel comprised of ten experienced judges and the wines were tasted blindly in random order. At each tasting the panel had to conduct three triangle tests, and one rank tasting where they had to rank the wines from least acceptable to most acceptable.

Wine $\mathrm{C}$ was evaluated after 12 and 24 weeks of micro-oxygenation. For the $3 \mathrm{mg} \mathrm{O} / \mathrm{L} /$ month treatment after 24 weeks, samples were also included that were drawn after 16 weeks of treatment. In samples of the $3 \mathrm{mg} \mathrm{O} / \mathrm{L} /$ month treatments, the $\mathrm{SO}_{2}$ concentration was also increased from $17 \mathrm{mg} / \mathrm{L}$ free to $30 \mathrm{mg} / \mathrm{L}$ free $12 \mathrm{~h}$ before the tasting. This was done to ascertain whether increasing the $\mathrm{SO}_{2}$ concentration had an effect on the sensory pro- 
file of the wine. The panel thus had to evaluate a control sample, a $1.5 \mathrm{mg} \mathrm{O} / 2 / \mathrm{L} /$ month treated sample, a $3 \mathrm{mg} \mathrm{O} / \mathrm{L} /$ month treated sample (after 16 weeks and 24 weeks), as well as a $3 \mathrm{mg}$ $\mathrm{O}_{2} / \mathrm{L} /$ month sample after 24 weeks in which the $\mathrm{SO}_{2}$ concentration had been increased. At these tastings members of the South African Pinotage Association, all experienced tasters of Pinotage, were used as a panel. At the initial tasting the members had to indicate, on an unstructured $10-\mathrm{cm}$ line scale, the intensities of fruitiness, oak associated flavours, astringency and bitterness. It was then decided to change these characteristics to fruitiness, spiciness, vanilla/butterscotch, oak wood/coconut, barnyard/medicinal, oxidised/aged, bitterness and astringency for the 24-week tasting. At this tasting each panel member also had to rank the wines according to preference. Wines $\mathrm{B}$ and $\mathrm{D}$ did not undergo sensory evaluation.

\section{Microbiological analysis}

Acetic acid bacteria and Brettanomyces yeasts in wine $\mathrm{C}$ were enumerated by plating out the wine on selective media at the beginning, and after 4, 14 and 20 weeks of micro-oxygenation. For the enumeration of acetic acid bacteria, the culture medium comprised $57 \mathrm{~g} / \mathrm{L}$ De Man Rogosa Sharpe (MRS) medium (pH adjusted to 5 with $\mathrm{HCl}, 20 \mathrm{~g} / \mathrm{L}$ agar) to which $20 \%$ sterile red wine $\mathrm{C}$ was added after sterilisation. This medium was supplemented with $7 \mathrm{mg} / \mathrm{L}$ penicillin (Sigma) and $50 \mathrm{mg} / \mathrm{L}$ pimaricin (Actistab, Gistbrocades, Anchor Yeast Biotechnologies) to eliminate lactic acid bacteria and yeast, respectively. Brettanomyces strains were isolated on a YPD medium [containing $10 \mathrm{~g} / \mathrm{L}$ yeast extract, $20 \mathrm{~g} / \mathrm{L}$ peptone, $20 \mathrm{~g} / \mathrm{L}$ glucose $(\mathrm{pH} 4.8$, adjusted with $\mathrm{HCl}, 20 \mathrm{~g} / \mathrm{L}$ agar)], supplemented with $50 \mathrm{mg} / \mathrm{L}$ chloramphenicol (Sigma) and $300 \mathrm{mg} / \mathrm{L}$ cyclohexamide (Sigma) to eliminate bacteria and non-Brettanomyces yeasts, respectively. Plates were incubated at $30^{\circ} \mathrm{C}$ for 10 days before counting the colonies.

\section{Standard wine analyses}

Vinlab Pty. Ltd., South Africa, an accredited laboratory, conducted certain standard analyses of wine A. Analyses included: $\mathrm{pH}$, total acidity, alcohol, residual sugar, volatile acidity, extract, free and total $\mathrm{SO}_{2}$. These analyses were carried out every three weeks according to the methods described by Iland et al. (2000). After 2002, the analyses, except the free and total $\mathrm{SO}_{2}$ analyses, of wines B, C and D were conducted with the GrapeScan FT 120 instrument (Foss Electric, Denmark) (Nieuwoudt et al., 2004). The instrument utilises Fourier-transform infrared spectroscopy (FT-IR). All samples were degassed by filtration prior to analysis, using the Filtration Unit (type 70500, Foss Electric, Denmark), and 185-mm diameter filter paper circles graded at 20-25 $\mu \mathrm{m}$. Sulphur dioxide analyses were carried out using the Metrohm titration unit (Metrohm Ltd., Switzerland).

\section{Statistical analysis}

The sensory results of wine A were statistically analysed as follows: The triangle tests were tested at the 0.05 and 0.01 probability level using the significance in triangle test $(\mathrm{p}=1 / 3)$. The ranking tasting was analysed at the probability level of 0.01 and 0.05 , according to Basker (1988). The ranking data of wine C was statistically analysed as for wine A. In addition, bootstraps analysis was performed on the intensities data, according to Efron and Tibshirani (1993)).

\section{RESULTS AND DISCUSSION}

\section{Colour and phenolic development}

As mentioned, normally one of the main obstacles to micro-oxygenation research is the large scale of experiments required, making it difficult to carry out the number of experiments required to obtain reproducibility of results. This research was conducted on only one sample per treatment and thus one should not consider the absolute values reported, but rather the tendencies observed. In wine A, micro-oxygenation led to a decrease in total phenolic concentrations (phenolic concentration was high in this wine) after seven to nine weeks, and the concentrations were even lower in the treated wines after 15 weeks (results not shown). A slight increase in total phenolic levels in the control tank was probably due to the contact of the wine with the oak staves, which can impart hydrolysable tannins to the wine (Peuch et al., 1999). The colour density (Fig. 1) increased in the treated wines, and was

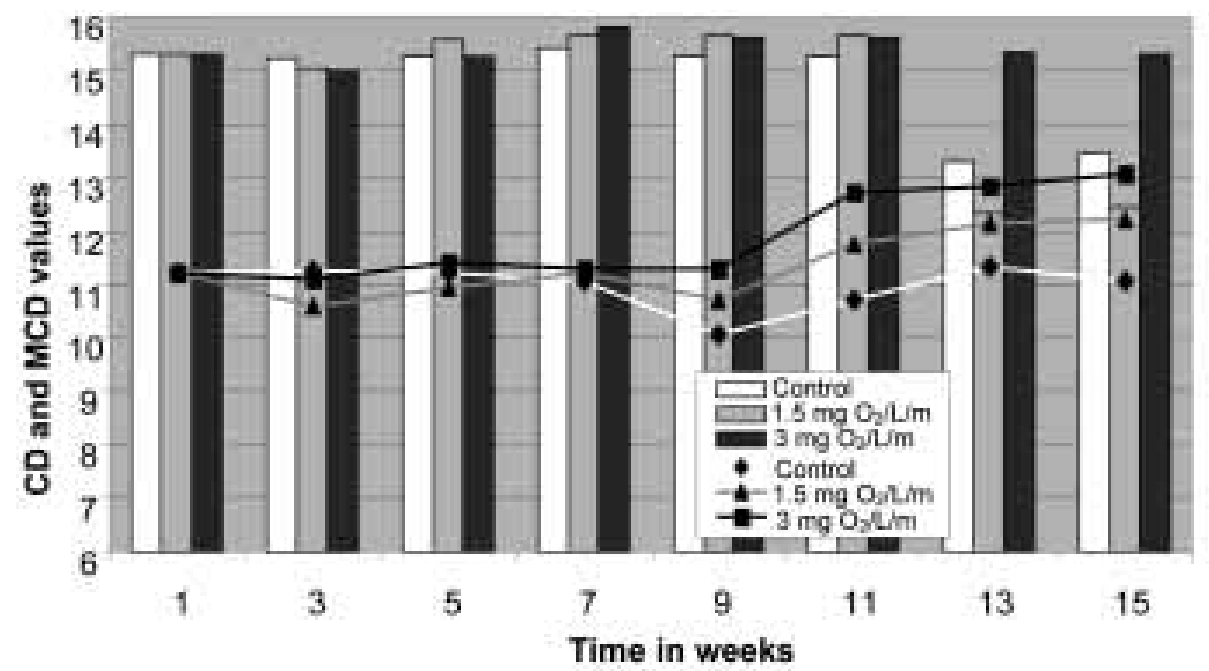

FIGURE 1

Colour (CD) (lines) and modified colour (bars) density (MCD) of wine A in absorbance units (AU) during micro-oxygenation treatment (see Table 1). 
also reflected in the polymeric colour increasing in the same wines (results not shown). The difference between the colour densities and modified colour densities was also smaller in the treated wines compared with the control for up to 11 weeks of the treatment, with the modified colour density decreasing in the control and the $1.5 \mathrm{mg} \mathrm{O}_{2} / \mathrm{L} / \mathrm{month}$ sample afterwards. The increase in colour was due to a greater proportion of colour pigments being in the red form, when incorporated in the polymeric colour form. However, after five weeks the percentage of pigments in the red form decreased, probably due to further polymerisation and precipitation (Fig. 2). In wine B, an increase in the colour density during 10 weeks of treatment was observed, with the polymeric pigment fraction being the dominant part of this wine's colour fraction at this stage (Figs. 3 and 4). These changes are due to colourless anthocyanins being transformed to red pigments due to interactions between nucleophilic C6 or C8 carbons of procyanidins with the electrophilic $\mathrm{C} 4$ of an anthocyanin molecule, form- ing colourless flavenes. Subsequent aeration, as with racking or the addition of $\mathrm{O}_{2}$ by micro-oxygenation, leads to the formation of the red form (Monagas et al., 2005). Oxidation of phenolic molecules also leads to the formation of $\mathrm{H}_{2} \mathrm{O}_{2}$, which oxidises ethanol to acetaldehyde. The latter can form a bridge between an anthocyanin molecule and a procyanidin moiety (Es-Safi et al., 1999). The resulting molecule is also coloured, subsequently leading to the increase in colour density during ageing, as observed in red wine in the barrel. Colour pigments also become more resistant to the bleaching effect of $\mathrm{SO}_{2}$, because the coloured polymerised fraction is less sensitive to $\mathrm{SO}_{2}$ bleaching due to steric hindrance. One of the alleged uses of micro-oxygenation is to simulate an oak barrel, leading to the observed colour changes (Santos-Buelga et al., 1999; Fourie, 2005).

The addition of $\mathrm{O}_{2}$ with micro-oxygenation does however not always lead to an increase in colour density, as found in other wines that were monitored. This was true for wine $\mathrm{D}$, which

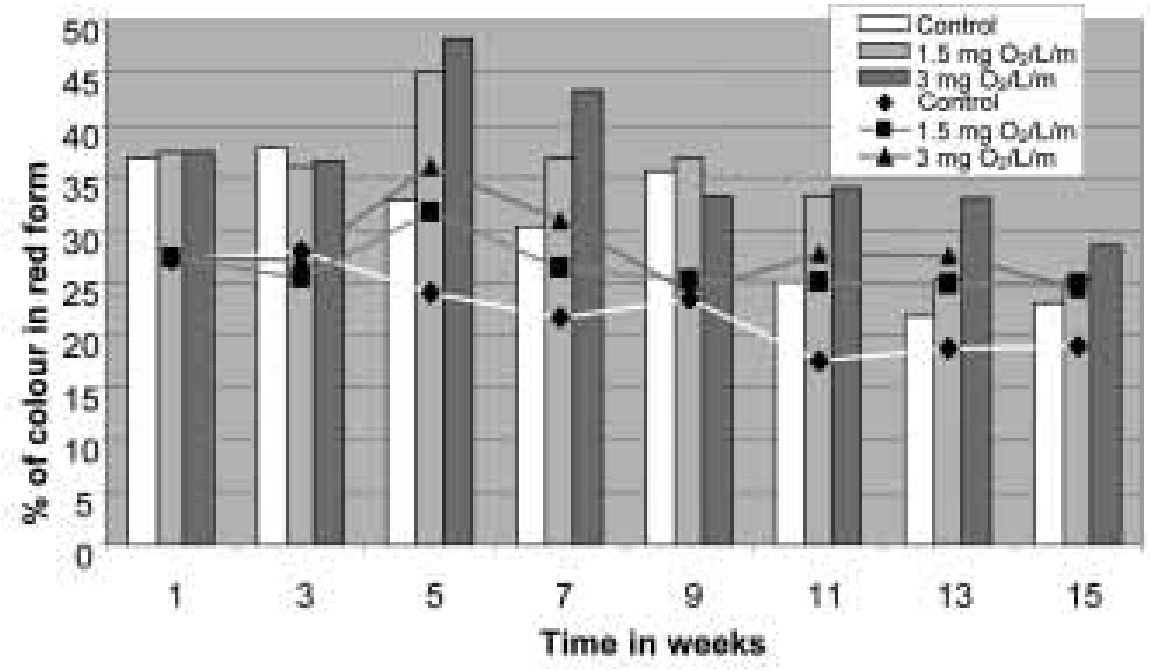

FIGURE 2

The percentage (lines) and modified percentage (bars) of colour in the red form of wine A (see Table 1) during micro-oxygenation treatment.

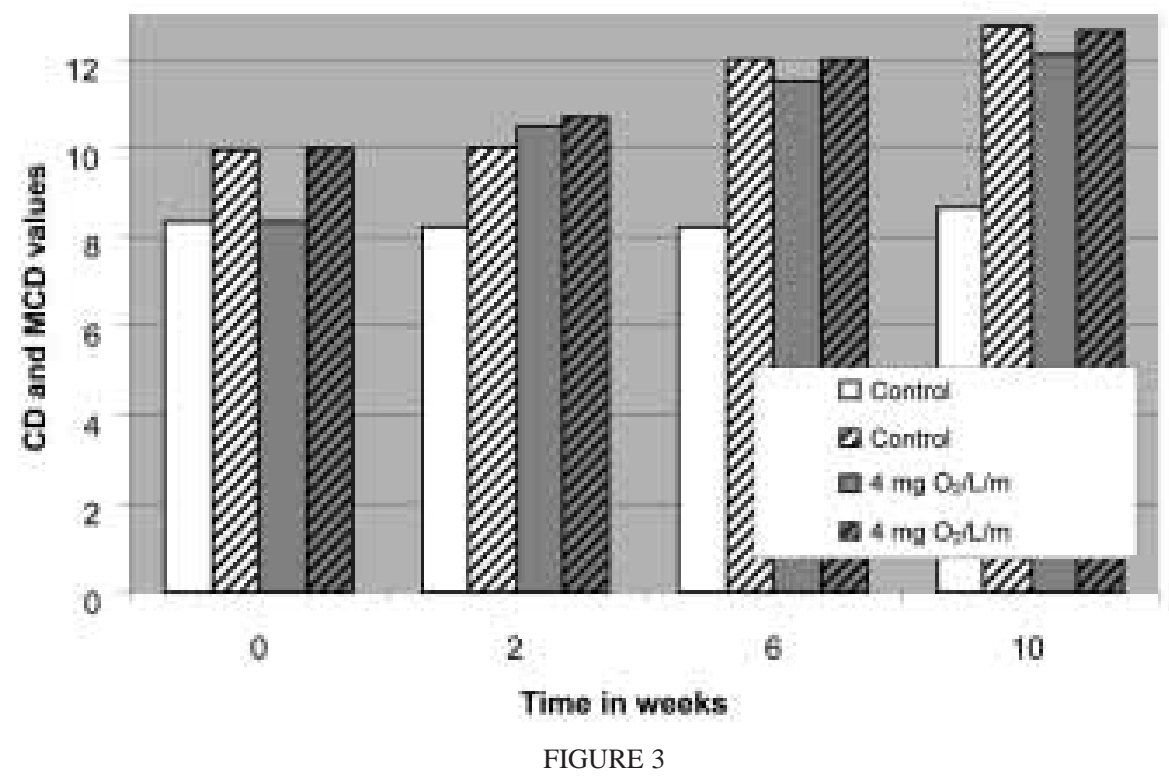

Colour (CD, open bars) and modified colour density (MCD, striped bars) of wine B in absorbance units (AU) during micro-oxygenation treatment (see Table 1). 


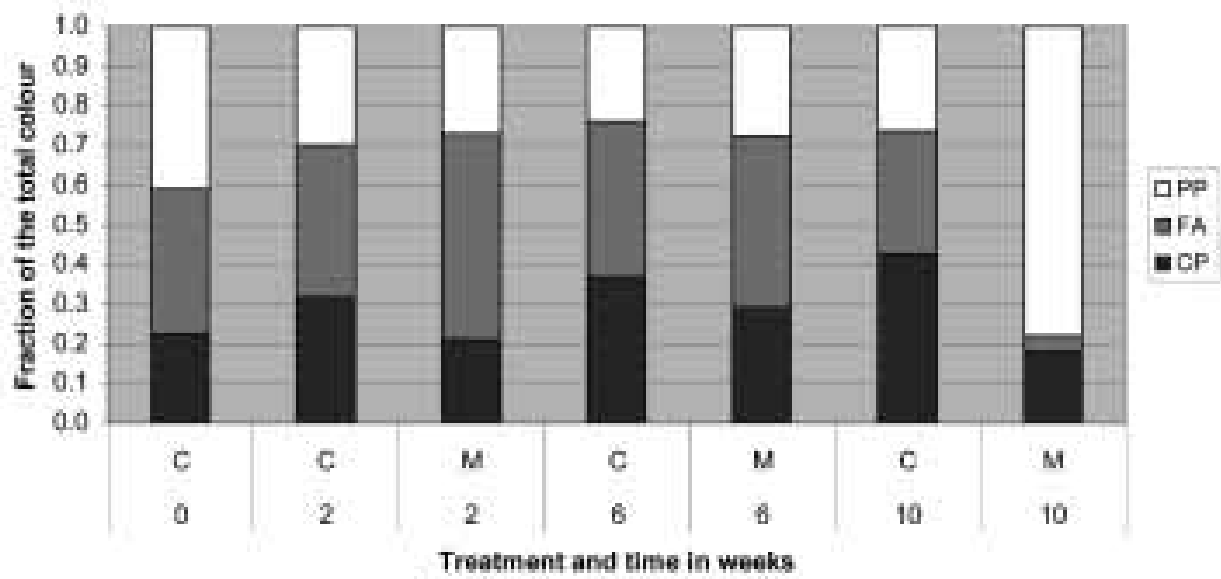

FIGURE 4

Development of the fraction of colour of wine B (see Table 1) during micro-oxygenation treatment. C: control tank, M: micro-oxygenation tank receiving $3 \mathrm{mg} \mathrm{O}_{2} / \mathrm{L} / \mathrm{month}$ (see Table 1). PP: fraction of colour due to polymeric fraction, FA: fraction of colour due to free anthocyanins, CP: fraction of colour due to co-pigmentation.

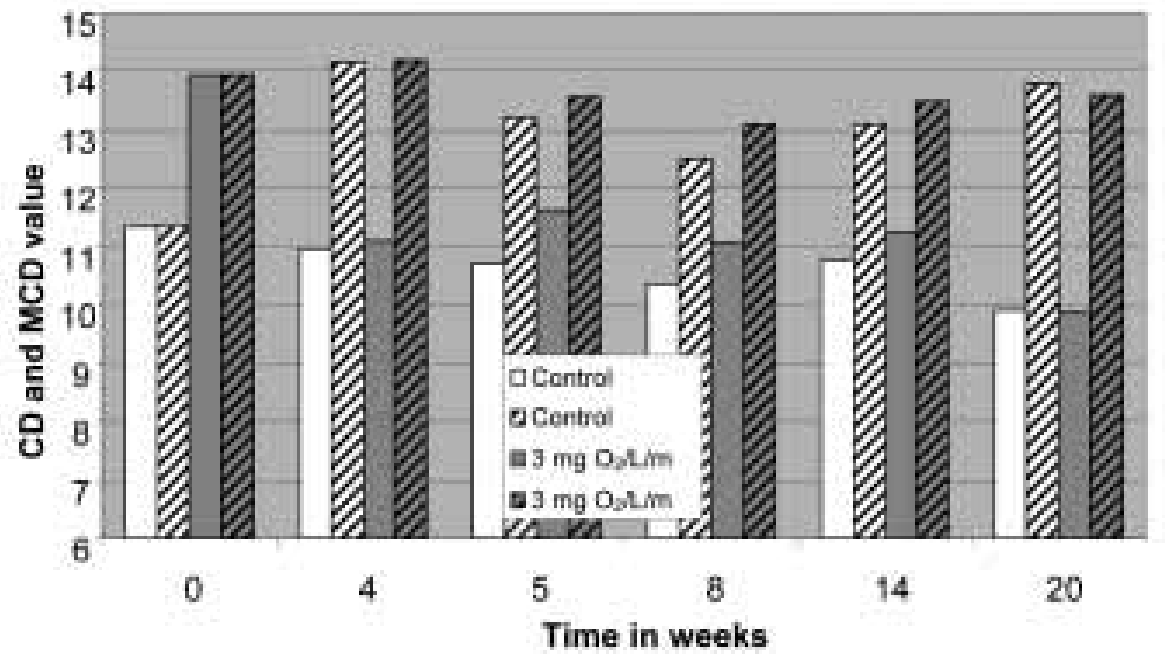

FIGURE 5

Colour (open bars) and modified (striped bars) colour density of wine D in absorbance units (AU) during micro-oxygenation treatment (see Table 1).

received $3 \mathrm{mg} \mathrm{O} / \mathrm{L} / \mathrm{month}$ (Fig. 5), as well as wine $\mathrm{C}$, which received 1.5 and $3 \mathrm{mg} \mathrm{O} / 2 / \mathrm{L}$ month for five months (Fig. 6). In wine $\mathrm{C}$, to which 1.5 - and $3 \mathrm{mg} \mathrm{O} / \mathrm{L} /$ month were added, the colour and modified colour densities did not differ dramatically over the 18 weeks' treatment time from that of the wine matured in the control tank and the barrel (results not shown). The modified colour density actually decreased after 10 weeks in all the treatments; it was about 12 in the $3 \mathrm{mg} \mathrm{O} / \mathrm{L} /$ month treatment and barrel wines compared to 11.5 after 18 weeks in the control tank and in the case of the $1.5 \mathrm{mg} \mathrm{O} / \mathrm{L} /$ month treatment. Colour density of the $3 \mathrm{mg} \mathrm{O}_{2} / \mathrm{L} /$ month tank was also one unit higher than that in the control tank at this stage (results not shown). It thus seems that micro-oxygenation does not always increase the colour intensities of red wine. It is more effective in younger red wines, just after the completion of malolactic fermentation, when a large proportion of the anthocyanins are still in the colourless pseudobase form, than in older wines (Ribéreau-Gayon et al., 2000). Total red pigments decreased as expected in all the treatments, but were slightly higher in the treated wines after 15-18 weeks than in the control (Fig. 6).

The HPLC results for wine $\mathrm{C}$ can be seen in Table 3 . Vanillic acid was much higher in the barrel-treated wine than in the other treatments, probably due to the higher oak contact. Catechin and procyanidin B1 concentrations decreased with increasing $\mathrm{O}_{2}$ addition over time, with the malvidin-3-glucoside concentration being lower in the control wine. This correlates with the spectrophotometric results. The procyanidin B1 concentration can also increase over time due to catechin associations, explaining the higher concentrations in the control wine after 24 weeks. The polymeric pigment increased in the $3 \mathrm{mg} \mathrm{O} / \mathrm{L} / \mathrm{month}$ and barrel treatments and was also higher in terms of polymeric phenols after 24 weeks of treatment. This is probably due to more 
TABLE 3

Concentrations of different phenolic compounds in wine C (see Table 1): initially and after 24 weeks of treatment.

\begin{tabular}{|c|c|c|c|c|c|}
\hline \multirow{2}{*}{ Compound } & \multicolumn{5}{|c|}{ Concentration $(\mathrm{mg} / \mathrm{L})$, for each treatment } \\
\hline & Initial & Control & $1.5 \mathrm{mg} \mathrm{O} / \mathrm{L} / \mathrm{month}$ & $3 \mathrm{mg} \mathrm{O} / \mathrm{L} / \mathrm{month}$ & Barrel \\
\hline Gallic acid & 46.4 & 56.1 & 50.3 & 57.2 & 47.3 \\
\hline Gentisic acid & 1.5 & 2.6 & nd & 1.5 & nd \\
\hline Caftaric acid & 17.3 & 16.3 & 17.5 & 16.8 & 17.3 \\
\hline Vanillic acid & 2.6 & 4.1 & 5.1 & 3.3 & 43.7 \\
\hline Catechin & 790.2 & 784.0 & 704.4 & 698.6 & 659.5 \\
\hline Caffeic acid & 64.2 & 59.0 & 56.8 & 57.0 & 52.6 \\
\hline Procyanidin B1 & 60.0 & 91.0 & 93.5 & 55.6 & 78.5 \\
\hline p-Coumaric acid & 3.6 & 3.8 & 4.2 & 6.4 & 12.2 \\
\hline Procyanidin B2 & 49.1 & 40.8 & 40.4 & 40.0 & 39.8 \\
\hline Epicatechin & 90.1 & 73.6 & 76.2 & 68.8 & 80.5 \\
\hline Delphinidin-3-glucoside & 11.2 & 7.7 & 7.4 & 9.6 & 7.2 \\
\hline Petunidin-3- glucoside & 13.8 & 7.6 & 9.3 & 8.5 & 8.7 \\
\hline Peonidin-3-glucoside & 5.5 & 2.9 & 4.1 & 3.4 & 4.1 \\
\hline Malvidin-3-glucoside & 117.9 & 63.4 & 83.8 & 72.0 & 79.6 \\
\hline Ellagic acid & 3.7 & 4.8 & 4.5 & 5.4 & 3.3 \\
\hline Quercetin-3- glucoside & 15.8 & 12.3 & 13.6 & 11.1 & 14.7 \\
\hline Myricetin & 4.3 & 3.2 & 5.1 & 5.1 & 4.3 \\
\hline Quercetin-3-rhamnoside & 5.0 & 4.2 & 3.4 & 4.7 & 4.0 \\
\hline Malvidin-3-acetate & 40.1 & 18.4 & 23.8 & 24.2 & 22.4 \\
\hline Quercitin & 7.8 & 4.8 & 6.4 & 5.8 & 5.2 \\
\hline Malvidin-3-p-coumaric acid & 19.6 & 6.8 & 11.1 & 9.6 & 10.0 \\
\hline Polymeric pigment & 28.8 & 29.0 & 33.9 & 34.8 & 35.3 \\
\hline Polymeric phenols & 791.6 & 782.9 & 947.1 & 1021.5 & 1132.0 \\
\hline
\end{tabular}

nd: not detected

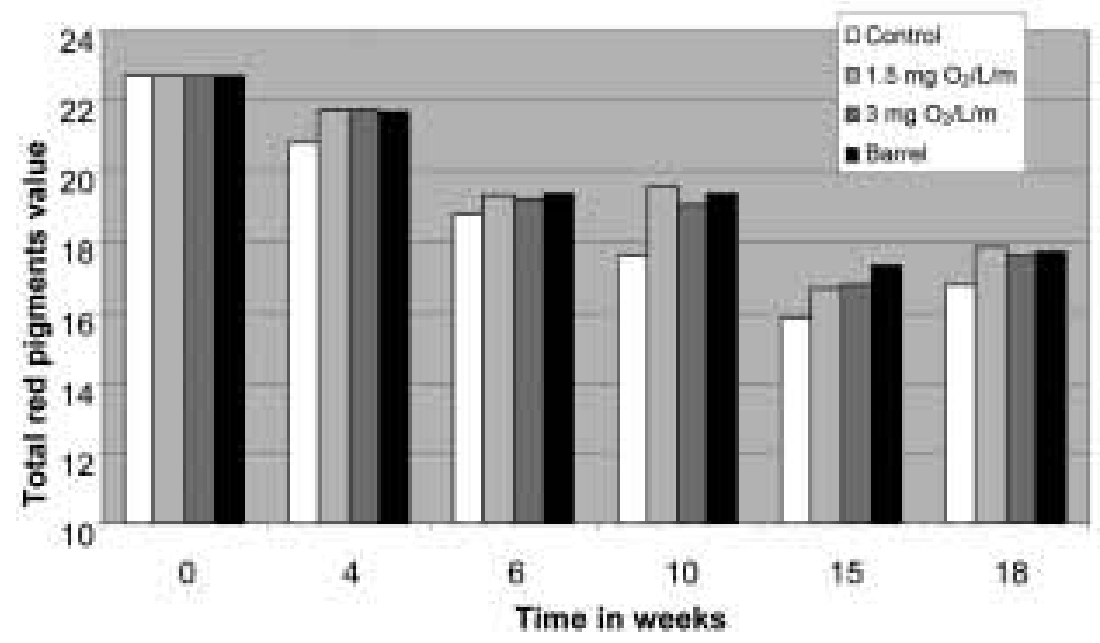

FIGURE 6

Total red pigment development of wine $\mathrm{C}$ in absorbance units (AU) during micro-oxygenation treatment (see Table 1).

acetaldehyde being produced in these treatments because of the higher $\mathrm{O}_{2}$ additions, which led to enhanced acetaldehyde polymerisation (Ribéreau-Gayon et al., 2000). The polymerisation of procyanidins in wine A was also reflected in an increase in the $\mathrm{HCl}$ index of the treated wines (Fig. 7). The formation of acetaldehyde from ethanol and glyoxylic acid from tartaric acid due to oxidation can lead to the polymerisation of catechin mole- cules (Drinkine et al., 2005). A small decrease in the total tannin concentration and a small increase in colour hue in the treated wines were observed (results not shown).

In wine $C$ the gelatine index varied over time and between the treatments (Fig. 8). This shows that the wine goes though different stages of reactivity towards proteins. The gelatine index is, however, only an indication of astringency and does not always corre- 


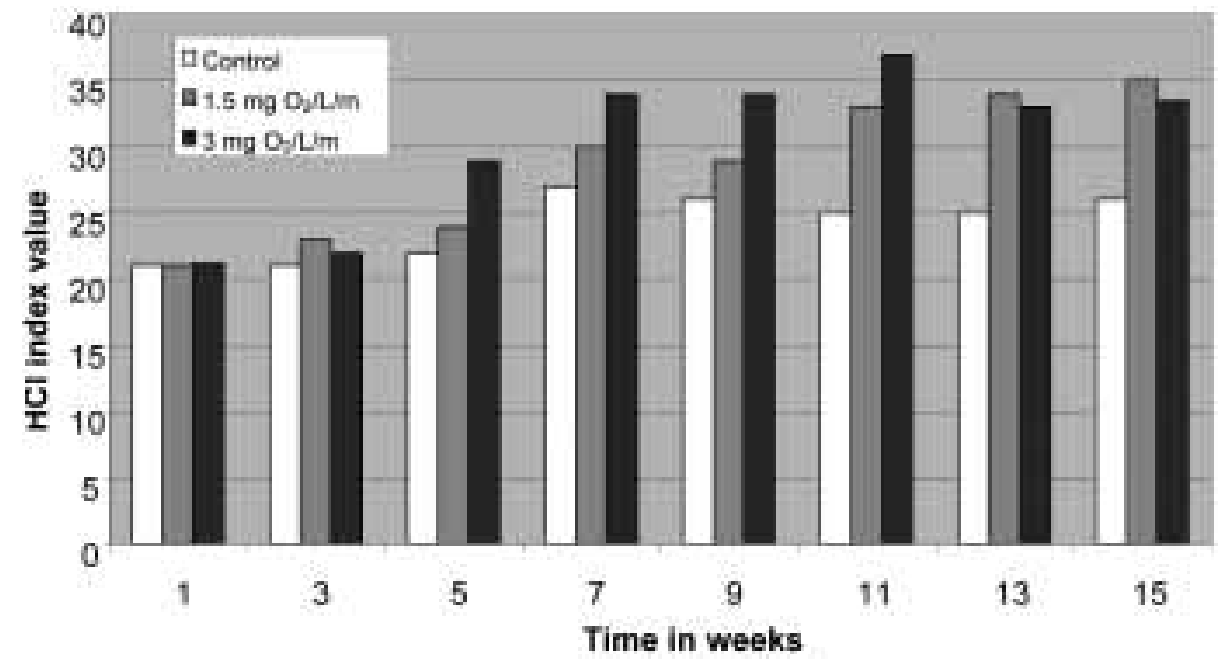

FIGURE 7

Degree of polymerisation of procyanidins ( $\mathrm{HCl}$ index value) of wine A during micro-oxygenation treatment (see Table 1).

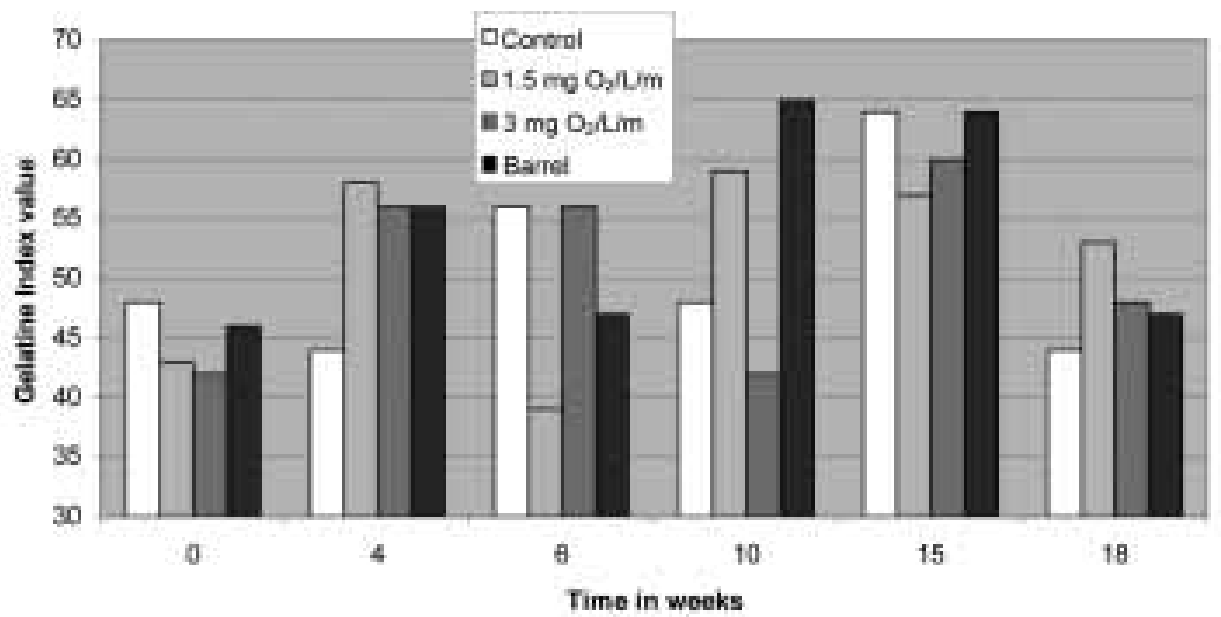

FIGURE 8

Reactivity of wine $\mathrm{C}$ towards proteins (gelatine index value, see Table 1) during micro-oxygenation treatment.

late directly with the astringency of a red wine (Ribéreau-Gayon et al., 2000). According to Parish et al. (2000), red wine first goes through a structuring stage after micro-oxygenation has started. During this stage the astringency increases. This is followed by the harmonisation phase, which is characterised by a decrease in astringency, but can be followed by a stage in which the wine becomes too hard or "dried out" if the micro-oxygenation is applied for too long. This correlates with results of Nikfardjam \& Dykes (2003). Our results also showed differences between the control and treated wines, but these were not correlated with astringency assessment through tastings. Clearly, more research is needed regarding the effect of micro-oxygenation and the effect of $\mathrm{O}_{2}$ addition to red wine on the sensory characteristics.

In this investigation tendencies were observed, but further trials investigating the effect of micro-oxygenation on the evolution of the taste of red wine should be carried out in future, with adequate repeats.

\section{Microbiological status}

Acetic acid bacteria and Brettanomyces are both well-known spoilage microorganisms of wine. Acetic acid bacteria can form elevated levels of acetic acid through the oxidative metabolism of ethanol. Brettanomyces can cause medicinal/barnyard characteristics in wine due to the production of volatile phenols. Both the abovementioned organisms have been proven to grow in wine when oxygen levels are increased (Du Toit \& Pretorius, 2002; Du Toit et al., 2005). According to our knowledge, to date, the effect of micro-oxygenation on acetic acid bacteria and Brettanomyces cell numbers in wine has not been reported. Figures 9 and 10 show the acetic acid bacteria and Brettanomyces numbers in wine $\mathrm{C}$ during micro-oxygenation. Acetic acid bacteria numbers decreased in the control tank after four weeks, but were generally higher in the tanks receiving $\mathrm{O}_{2}$ and in the barrel (Fig. 9). Acetic acid bacteria can reach a viable but non-culturable state in wine that can be negated by the addition of $\mathrm{O}_{2}$, as could happen 
when micro-oxygenation is applied to the wine (Du Toit et al., 2005).

Brettanomyces counts increased in the $1.5 \mathrm{mg} \mathrm{O} / \mathrm{L} / \mathrm{month}$ treatment from $10^{1}$ to $10^{3} \mathrm{cfu} / \mathrm{mL}$ after 14 weeks (Fig. 10). At this point the free $\mathrm{SO}_{2}$ concentration decreased in this tank to 18 $\mathrm{mg} / \mathrm{L}$, and was then increased to $35 \mathrm{mg} / \mathrm{L}$. This led to a decrease in Brettanomyces cell counts in this tank. The counts in the $3 \mathrm{mg}$ $\mathrm{O}_{2} / \mathrm{L} / \mathrm{month}$ tank increased, with a correlating decrease in the free $\mathrm{SO}_{2}(17 \mathrm{mg} / \mathrm{L})$ at week 20 . At this stage, the $\mathrm{SO}_{2}$ was then adjusted to $35 \mathrm{mg} / \mathrm{L}$ in all the treatments. Therefore, micro-oxygenation does not seem to support the growth of acetic acid bacteria but possibly supports their survival. With the permeation of $\mathrm{O}_{2}$ through oak staves (Vivas et al., 2003), small amounts of $\mathrm{O}_{2}$ coming into contact with wine could hence support the survival of acetic acid bacteria and Brettanomyces in the barrel and oxygentreated wines. The judicial use and monitoring of $\mathrm{SO}_{2}$ in combination with micro-oxygenation is important to prevent this, especially in the case of Brettanomyces. Excessively high $\mathrm{SO}_{2}$ concentrations could, however, lead to inhibition of favourable phenolic polymerisation reactions (Ribéreau-Gayon et al., 2000).

\section{Sensory results}

The triangle tasting of wine A after eight weeks of treatment revealed that there was a significant difference between the control and the $3 \mathrm{mg} \mathrm{O}_{2} / \mathrm{L} / \mathrm{month}$ treatment ( $\mathrm{p} \leq 0.05$, results not shown). The same level of significance was found when the panel had to distinguish between the $1.5 \mathrm{mg} \mathrm{O} / 2 / \mathrm{L} /$ month and $3 \mathrm{mg} \mathrm{O} / \mathrm{L} / \mathrm{month}$ treatments. The panel was unable to distinguish between the control and the $1.5 \mathrm{mg} \mathrm{O}_{2} / \mathrm{L} /$ month treated wines, but was able to distinguish between the control and the $3 \mathrm{mg} \mathrm{O} / \mathrm{L} / \mathrm{month}$ treated wine. At both significance levels ( $\mathrm{p} \leq 0.05$ and $\mathrm{p} \leq 0.01$ ), the $3 \mathrm{mg}$ $\mathrm{O}_{2} / \mathrm{L} / \mathrm{month}$ treated wine was preferred to the control, and to the $1.5 \mathrm{mg} \mathrm{O} / \mathrm{L} / \mathrm{month}$ treatment $(\mathrm{p} \leq 0.05$ ). At this stage there was no significant difference regarding preference between the control and the $1.5 \mathrm{mg} \mathrm{O}_{2} / \mathrm{L} / \mathrm{month}$ treated wine.

After 12 weeks, the triangle tests showed that there was a significant difference $(\mathrm{p} \leq 0.01)$ level; the panel could distinguish between the control and the $1.5 \mathrm{mg} \mathrm{O}_{2} / \mathrm{L} /$ month treatment. The same level of significance was found when the panel had to distinguish between the control and the $3 \mathrm{mg} \mathrm{O} / \mathrm{L} / \mathrm{month}$ treatment and between the $1.5 \mathrm{mg} \mathrm{O} / \mathrm{L} / \mathrm{month}$ and $3 \mathrm{mg} \mathrm{O} / \mathrm{L} / \mathrm{month}$ treat-

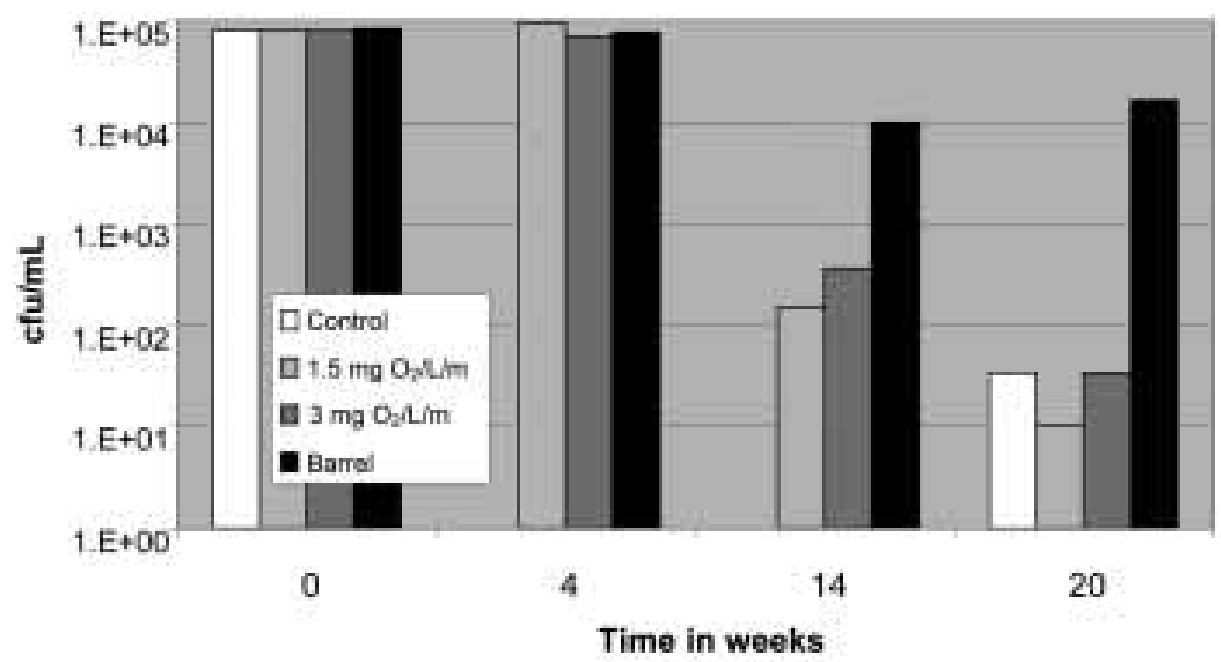

FIGURE 9

Acetic acid bacterial numbers in wine $\mathrm{C}$ during micro-oxygenation treatment (see Table 1).

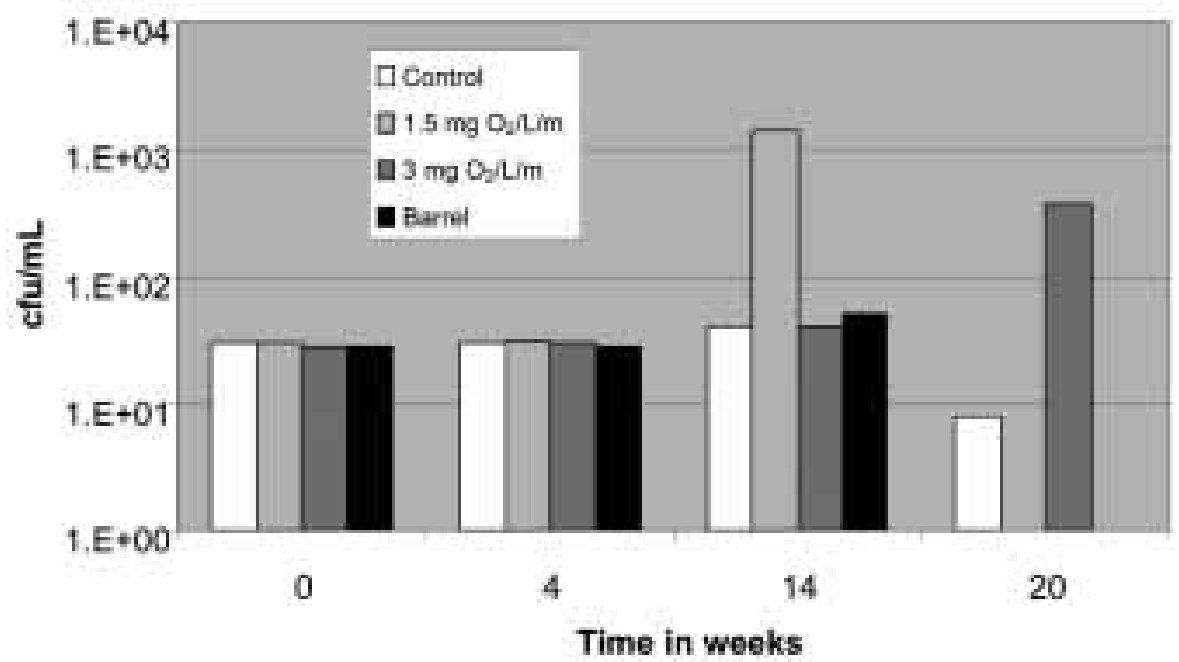

FIGURE 10

Brettanomyces numbers in wine $\mathrm{C}$ during micro-oxygenation treatment (see Table 1). 


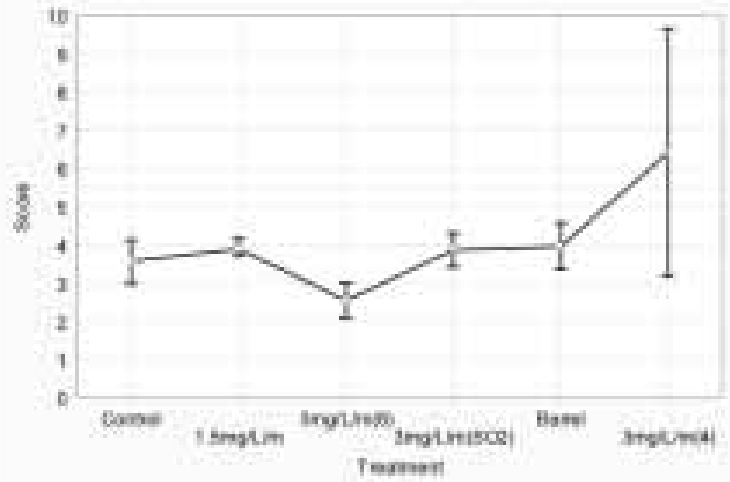

Spiciness

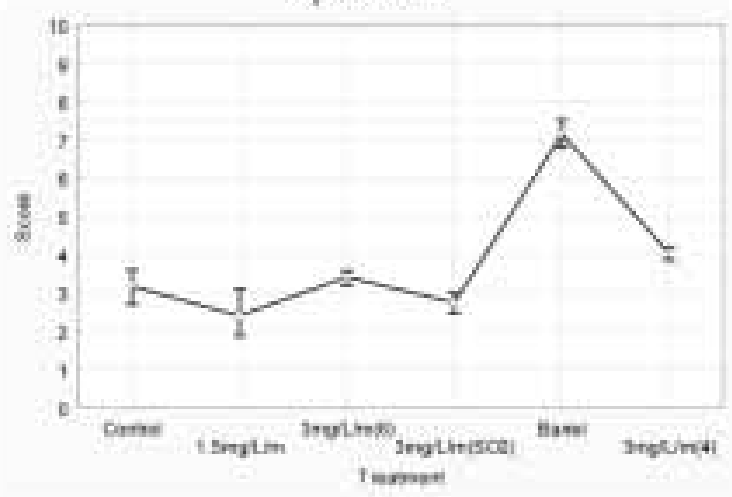

Vanilla/butterscotch

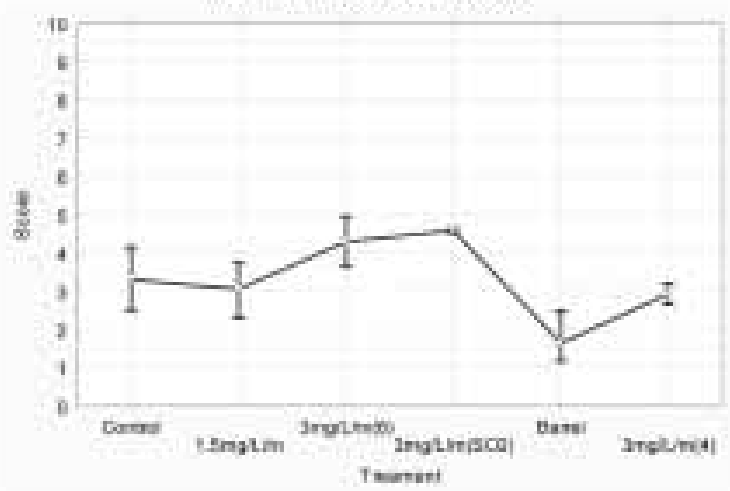

Barnyard/medicinal

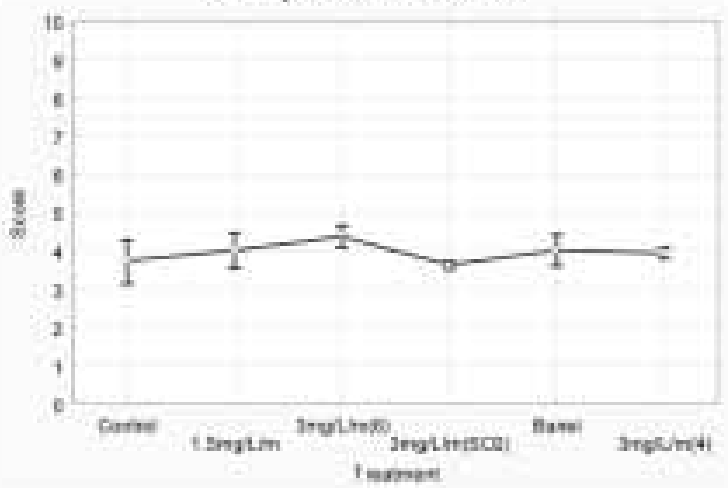

Astringency

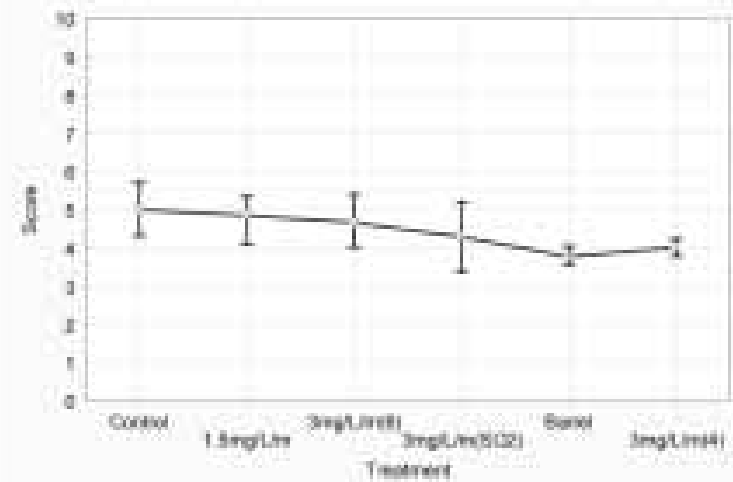

Fruitiness

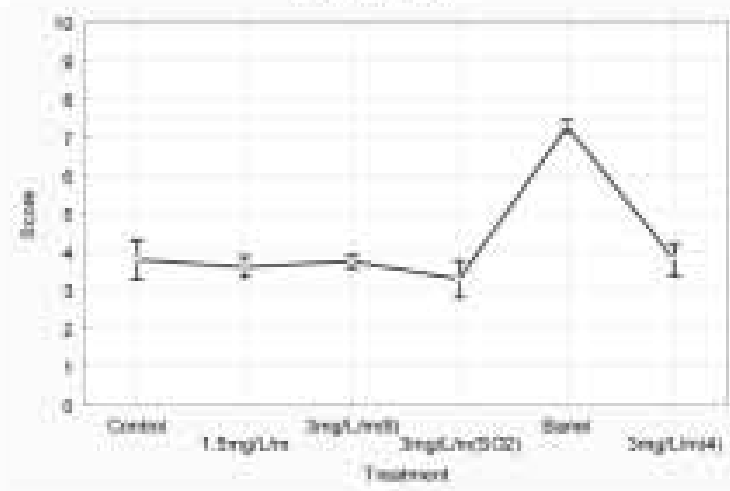

Oak/coconut

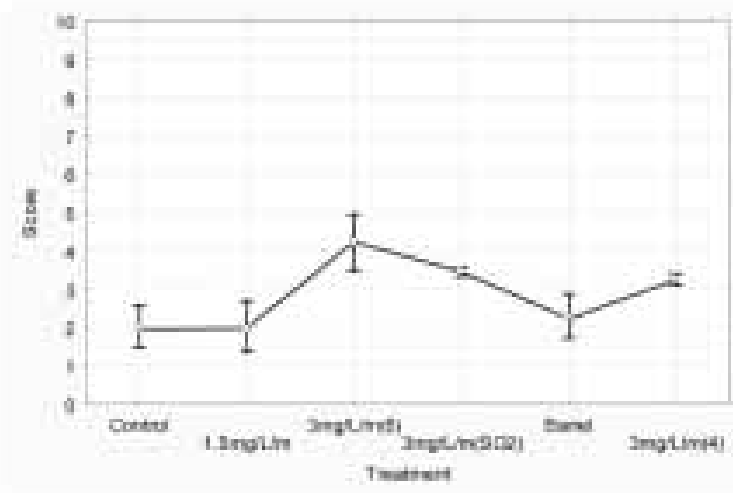

Oxidised/aged

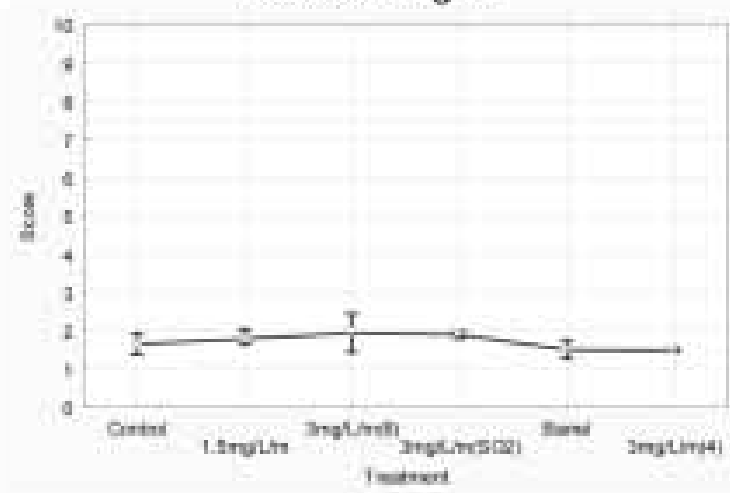

Bitterness

FIGURE 11

Score plots of bootstrap confidence intervals of different sensory attributes of wine $\mathrm{C}$ after 6 months of micro-oxygenation (6). In the 3 mg $\mathrm{O}_{2} / \mathrm{L} / \mathrm{month}$ treatment wines were also evaluated (see Table 1) after 4 months (4), and included samples to which $\mathrm{SO}_{2}$ was added prior to the tasting $\left(\mathrm{SO}_{2}\right)$. Vertical bars denote 0.95 bootstrap confidence interval. 
ments. At a significance level of $\mathrm{p} \leq 0.05$, the $3 \mathrm{mg} \mathrm{O} / \mathrm{L} / \mathrm{month}$ treatment was preferred to the $1.5 \mathrm{mg} \mathrm{O} / \mathrm{L} /$ month treatment. The $1.5 \mathrm{mg} \mathrm{O} / \mathrm{L} / \mathrm{month}$ treatment was also preferred to the control at this level of statistical significance $(\mathrm{p} \leq 0.05)$. At a significance level of $\mathrm{p} \leq 0.01$ the $3 \mathrm{mg} \mathrm{O} / \mathrm{L} / \mathrm{month}$ treatment was preferred to the control after 12 weeks of micro-oxygenation. In this younger red wine, micro-oxygenation thus led to these wines being preferred over the control wines, and this phenomenon occurred faster at the higher $\mathrm{O}_{2}$ dosage.

Wine $\mathrm{C}$ was tasted twice. In the initial tasting (after three months) the panel could not statistically distinguish between the control, the 1.5 - and $3 \mathrm{mg} \mathrm{O}_{2} / \mathrm{L} / \mathrm{month}$ treatments, and the barrel wines, on an intensity tasting for bitterness and astringency (results not shown). The panel rated the barrel-matured wine much higher in terms of oak wood character and lower in terms of fruitiness. This was probably due to the masking effect that the oak flavour compounds had on the fruity character. This highlighted the need for further research regarding the use of oak staves in conjunction with micro-oxygenation to simulate storage in barrels, because the oak stave dosage was conducted according to the supplier's recommendations. The panel also did not have a significant preference for a certain treatment.

It is clear that the bootstrap means for the fruity and spicy attributes did not differ significantly between the treatments, although the former was slightly lower in the barrel treatment (second tasting after six months, Fig. 11). Astringency and bitterness also did not differ significantly, but the oak wood/coconut and vanilla/butterscotch attributes were significantly higher in the barrel treatment than in the other treatments. This also explains the previously mentioned lower perceived levels of fruitiness due to the masking effect of the oak wood aromas. Oxidised/aged and barnyard/medicinal flavours were higher in the $3 \mathrm{mg} \mathrm{O} / / \mathrm{L} / \mathrm{month}$ treatment at this stage. The addition of $\mathrm{SO}_{2}$ to these samples lowered the perception of the oxidised/aged character slightly. $\mathrm{SO}_{2}$ binds acetaldehyde, lowering its perception in wine, but it seems that the oxidised aroma of wine is not correlated with the acetaldehyde concentration (Silva Ferreira et al., 2002). The barnyard/medicinal character also increased in the $3 \mathrm{mg}$ $\mathrm{O}_{2} / \mathrm{L} / \mathrm{month}$ treatment between four and six months of treatment.

At a significance level of $\mathrm{p} \leq 0.05$, the panel preferred the control, the $1.5 \mathrm{mg} \mathrm{O}_{2} / \mathrm{L} /$ month tank, the barrel treatments and the 3 $\mathrm{mg} \mathrm{O}_{2} / \mathrm{L} /$ month samples taken after four months, rather than the $3 \mathrm{mg} \mathrm{O} / \mathrm{L} / \mathrm{month}$ treatment at the six months stage (results not shown). The panel did not, however, have statistically significant preferences between the $3 \mathrm{mg} \mathrm{O} / \mathrm{L} / \mathrm{month}$ treatment taken after four months of micro-oxygenation, the control, the $1.5 \mathrm{mg}$ $\mathrm{O}_{2} / \mathrm{L} / \mathrm{month}$ and the barrel treatments. This highlights the fact that when micro-oxygenation is applied for too long the wine can become over-aged/developed, with a resulting decrease in quality. The barnyard/medicinal aromas, normally associated with Brettanomyces spoilage, also correlated with the increase in Brettanomyces counts after 14 and 20 weeks in the $1.5 \mathrm{mg}$ $\mathrm{O}_{2} / \mathrm{L} / \mathrm{month}$ and $3 \mathrm{mg} \mathrm{O} / \mathrm{L} /$ month treatments (Fig. 10). It is thus also doubtful whether micro-oxygenation is effective in an older red wine because the panel did not have a clear preference for the $\mathrm{O}_{2}$ treated wines over the control. Nikfardjam and Dykes (2003) found that that the wine becomes too astringent when micro-oxygenation is applied for too long. This correlates with a mean degree of polymerisation of procyanidins that is too high.

\section{Standard wine analysis}

Minor changes took place during the different treatments in terms of standard analysis (results not shown). The largest change took place in the free $\mathrm{SO}_{2}$ concentration, where decreases from 25$30 \mathrm{mg} / \mathrm{L}$ to $17-20 \mathrm{mg} / \mathrm{L}$ free $\mathrm{SO}_{2}$ were observed after six to twelve weeks of micro-oxygenation in the different wines. Alcohol, volatile acidity, total acidity, residual sugar and $\mathrm{pH}$ values remained the same during the treatments.

\section{CONCLUSIONS}

Micro-oxygenation has an influence on the phenolic composition and quality of red wine. To date, micro-oxygenation has not been investigated in detail under South African conditions. This study has shown that under certain circumstances micro-oxygenation can lead to enhanced colour densities, with the colour becoming less prone to $\mathrm{SO}_{2}$ bleaching, although this does not seem to be the case with older red wines. Micro-oxygenation can be used to enhance the quality of a younger red wine, but should be used with care in an older red wine because over-oxidation can lead to a faulty/spoiled character. The $\mathrm{SO}_{2}$ levels of the wine should be checked regularly because Brettanomyces growth during micro-oxygenation can lead to unwanted medicinal flavours. Micro-oxygenation can also lead to higher acetic acid bacteria numbers. Phenolic development in a wine that received $3 \mathrm{mg} \mathrm{O}_{2} / \mathrm{L} /$ month was on par with the same wine matured in an oak barrel. More research into this is required, especially to investigate the validity of the recommendations of suppliers of oak staves, where they are used in combination with microoxygenation to simulate oak barrel storage. However, if used correctly, micro-oxygenation can be applied with success to bring about favourable changes in a red wine.

Clearly, more research on micro-oxygenation as well as the effect of oxygen on red wine composition in general should be carried out. The authors suggest that the current practical difficulties associated with being able to carry out an adequate number of repeatable micro-oxygenation experiments can be overcome by manufacturing and using a system that can accurately dose $\mathrm{O}_{2}$ in small amounts, in small tanks, thus reducing the volumes of wine required.

\section{LITERATURE CITED}

Basker, D., 1988. Critical values of difference among rank sums for multiple comparisons by small taste panels. Food Techn. 41, 88-89.

Boulton, R., 2001. The copigmentation of anthocyanins and its role in the color of red wine: a critical review. Am. J. Enol. Vitic. 52, 67-87.

Drinkine, J., Glories Y., \& Saucier, C., 2005. (+)-Catechin-aldehyde condensations: competition between acetaldehyde and glyoxylic acid. J. Agric. Food Chem. 53, 7552-7558.

Du Toit, W.J. \& Pretorius, I.S., 2002. The occurrence, control and esoteric effect of acetic acid bacteria in winemaking. Ann. Microbiol. 52, 155-179.

Du Toit, W.J., Pretorius, I.S. \& Lonvaud-Funel, A., 2005. The effect of sulphur dioxide and oxygen on the viability and culturability of a strain of Acetobacter pasteurianus and a strain of Brettanomyces bruxellensis isolated from wine. J. Appl. Microbiol. 98, 862-871.

Efron, B. \& Tibshirani, R.J., 1993. An introduction to bootstrap. Chapman and Hall, New York, USA.

Es-Safi, N.-E., Fulcrand, H.L., Cheynier, V. \& Moutounet, M., 1999. Studies on the acetaldehyde-induced condensation of (-)-epicatechin and malvidin-3-O-glucoside in a model solution system. J. Agric. Food Chem. 47, 2096-2102.

Fourie, B.P., 2005. The influence of different barrels and oak derived products on the colour evolution and quality of red wines. MSc Agric. thesis, Stellenbosch University, Private Bag X1, 7602 Matieland (Stellenbosch), South Africa. 
Iland, P., Ewart, A., Sitters, J., Markides, A. \& Bruer, N., 2000. Techniques for chemical analysis and quality monitoring during winemaking. (1st Edition). Patrick Iland wine promotions, Campbelltown, Australia.

Monagas, M., Bartolome, B. \& Gomez-Cordoves, C., 2005. Updated knowledge about the presence of phenolic compounds in wine. Crit. Rev. Food Sc. Nutr. 45, $85-118$.

Nikfardjam, M. \& Dykes, S., 2003. Micro-oxygenation research at Lincoln University, Part 3: Polyphenolic analysis of Cabernet Sauvignon wine under the application of micro-oxygenation. The Austr. and New Zeal. Grapegrower \& Winemaker 468, 41-44.

Nieuwoudt, H.H., Prior, B.A., Pretorius, I.S., Manley, M. \& Bauer, F.F. 2004. Principal component analysis applied to Fourier transform infrared spectroscopy for the design of calibration sets for glycerol prediction models in wine and for the detection and classification of outlier samples. J. Agric. Food Chem. 52, 3728-3735.

Parish, M., Wollan, D. \& Paul, R., 2000. Micro-oxygenation - a review. The Austr. and New Zeal. Grapegrower \& Winemaker, Annual Technical Issue 438a, 47-50.
Puech, J. L., Feuillat, F. \& Mosedale, J.R., 1999. The tannins of oak heartwood: structure, properties, and their influence on wine flavor. Am. J. Enol. Vitic. 50, 469-478.

Ribéreau-Gayon, P., Glories, Y., Maujean, A. \& Dubourdieu, D., 2000. The chemistry of wine stabilization and treatments. In: Ribéreau-Gayon P. (ed.). Handbook of Enology, vol 2.. Wiley, Chichester, England.

Santos-Buelga, C., Francia-Aricha, E. M., Du Pascual-Teresa, S. \& RivasGonzalo, J. C., 1999. Contribution to the identification of the pigments responsible for the browning of anthocyanin-flavanol solutions. Europ. Food Research Techn. 209, 411-415.

Silva Ferreira, A.C., Barbe, J.C. \& Bertrand, A., 2002. Kinetics of oxidative degradation of white wines and how they are affected by selected technological parameters. J. Agric. Food Chem. 50, 5919-5924.

Vivas, N., Viva, N., Debèda, N., Vivas de Gaujelac, N. \& Nonier, M. F., 2003. Mise en évidence du passage de l'oxygène au travers des douelles constituents les barriques par l'utilisation d'un dispositif original de mesure de la porosité du bois. Premiere resultats. Sci.des Alim. 23, 655-678. 